IZA DP No. 7976

A Tale of Minorities: Evidence on Religious Ethics and Entrepreneurship from Swiss Census Data

Luca Nunziata

Lorenzo Rocco

February 2014 


\title{
A Tale of Minorities: Evidence on Religious Ethics and Entrepreneurship from Swiss Census Data
}

\author{
Luca Nunziata \\ University of Padua \\ and IZA \\ Lorenzo Rocco \\ University of Padua
}

\author{
Discussion Paper No. 7976 \\ February 2014
}

\author{
IZA \\ P.O. Box 7240 \\ 53072 Bonn \\ Germany \\ Phone: +49-228-3894-0 \\ Fax: +49-228-3894-180 \\ E-mail: iza@iza.org
}

Any opinions expressed here are those of the author(s) and not those of IZA. Research published in this series may include views on policy, but the institute itself takes no institutional policy positions. The IZA research network is committed to the IZA Guiding Principles of Research Integrity.

The Institute for the Study of Labor (IZA) in Bonn is a local and virtual international research center and a place of communication between science, politics and business. IZA is an independent nonprofit organization supported by Deutsche Post Foundation. The center is associated with the University of Bonn and offers a stimulating research environment through its international network, workshops and conferences, data service, project support, research visits and doctoral program. IZA engages in (i) original and internationally competitive research in all fields of labor economics, (ii) development of policy concepts, and (iii) dissemination of research results and concepts to the interested public.

IZA Discussion Papers often represent preliminary work and are circulated to encourage discussion. Citation of such a paper should account for its provisional character. A revised version may be available directly from the author. 
IZA Discussion Paper No. 7976

February 2014

\section{ABSTRACT}

\section{A Tale of Minorities: Evidence on Religious Ethics and Entrepreneurship from Swiss Census Data*}

Does Protestantism favour the market economy more than Catholicism does? We provide a novel quasi-experimental way to answer this question by comparing Protestant and Catholic minorities using Swiss census data from 1970 to 2000. Exploiting the strong adhesion of religious minorities to their confession's ethical principles and the historical determination of the geographical distribution of confessions across Swiss cantons, we find that Protestantism is associated with a significantly higher propensity for entrepreneurship. The estimated difference ranges between 2.3 and 4.4 percentage points. Our findings are robust to a number of robustness checks, including a placebo test.

JEL Classification: Z12, J24, J21, Z13

Keywords: entrepreneurship, self-employment, religion, culture, Protestantism, Catholicism, Switzerland

Corresponding author:

Lorenzo Rocco

Department of Economics

University of Padua

Via del Santo 33

35121 Padua

Italy

E-mail: Iorenzo.rocco@unipd.it

\footnotetext{
* We thank Giulia Tura for excellent research assistance and the seminar participants at the University of Bologna and ASREC for comments and suggestions. The usual disclaimer applies.
} 


\section{Introduction}

Economists and social scientists have often argued about the implications of religious ethics on economic activity. In Weber's view (Weber, 1904) the root of capitalism could be related to the emergence of Protestant ethical principles. These principles were more compatible with the secular activities attached to the new economic order than were those of Catholicism, since the Protestant principles emphasised individualism and work ethic and were favourable to individual achievement and success. However, some authors criticised Weber's analysis arguing that capitalistic development pre-dated the Reformation (Tawney, 1926) and most of the evidence to date has failed to confirm the hypothesis.

Recent contributions have renewed the debate about the correctness of Weber's thesis. Becker and Woessmann (2009) argue that Protestantism affected economic activity in Prussia by increasing education through the precept of personal reading of the Bible rather than through the ethical principles suggested by Weber. Cantoni (2010)'s analysis of historical German data suggests no effect of Protestant ethic on economic growth. Arrunada (2010) finds that Protestants work longer hours and have a stronger sense of the rule of law than Catholics do.

We add to this debate by looking at entrepreneurship, one of the fundamental features of capitalism and the market economy. ${ }^{1}$ The economic literature on entrepreneurship suggests that the fundamental determinants of the individual decision to become an entrepreneur are the presence of a generic entrepreneurship ability and risk aversion. (See Parker, 2005 for a review). According to the psychological literature, a propensity for entrepreneurship depends on individual psychological traits, such as determination, risk aversion, the need for achievement, resilience, self-confidence, a sense of independence and sense of life (McClelland, 1961; Cuervo, 2005; Renneboog and Spaenjers, 2012). McClelland (1961) suggests that all these attributes may be significantly influenced by the ethical principles inherent in Protestantism and Catholicism.

However, how deeply individuals internalise religious ethical principles is difficult to determine, as whatever their formal affiliation to a particular confession, individuals can differ substantially in the degree to which they adhere to their religions' ethics and in the

\footnotetext{
${ }^{1}$ We use the words "entrepreneur" and "self-employed" interchangeably.
} 
degree to which they take their religious affiliations seriously. In any case, people tend to report the confession in which they were raised, regardless of their current degree of adhesion. Therefore, religious affiliation is often a poor proxy for the canons, ethics, and codes of conduct that characterise each individual. ${ }^{2}$

We propose a novel strategy to overcome such difficulty and, more generally, to identify the causal effect of religious ethics on economic outcomes. Our research design exploits the fact that religious minorities tend to adhere more strongly to their confessions' ethical principles than do those who practice the majority religion (see Nunziata and Rocco, 2014 and the references therein) because religion is an important component of their identity that is worth defending against the influence of the majority. In addition, ministers of minority religions must work hard to preserve their herd, and minorities are subject to the pressure of the dominant religion (or, more generally, of the dominant culture) that only the more observant are able to resist.

In comparing Catholic and Protestant minorities, we extract the differential effects of these diverse ethical principles on entrepreneurship, under the hypothesis that religious minorities are alike in all other dimensions relevant to entrepreneurship. ${ }^{3}$

Our focus is on Switzerland for several reasons. First, Switzerland is an homogeneous territory in terms of its general economic conditions. Second, its peculiar historical and religious background led Swiss cantons to host a variety of combinations of Protestant and Catholic minorities and majorities. Third, the confessions' geographical distribution is historically determined with an almost perfect persistence over time. Fourth, Swiss Protestantism, represented by the Swiss Reformed Church, is relatively homogeneous in terms of its ethical principles, even though it derives from the Zwinglian tradition in the German cantons and from the Calvinist tradition in the French cantons.

The analysis of Swiss Census data from 1970 to 2000 shows that religious ethics significantly affects economic behaviour and outcomes. Our findings indicate that adherence to Protestant ethical principles increases the probability that an individual will be an entrepreneur by between 2.3 and 4.4 percentage points with respect to Catholics, after

\footnotetext{
${ }^{2}$ For example, only 20 percent of western Europeans believe in life after death, although 70 percent are self-declared Christians (International Social Survey Programme Religion II data, 1998).

${ }^{3}$ Unlike Weber and other authors, we do not investigate the historical process that led to the development of capitalism. Instead, we provide an empirical investigation of the religious ethical determinants of economic behaviour in a contemporary economy.
} 
controlling for a number of individual-level characteristics, including education and native language; as well as canton-level controls, including activity rate and the proportion of active people involved in agriculture; and regional-by-time unobservable heterogeneity.

We also find that the effect of religious ethics is driven primarily by highly skilled and prime age entrepreneurs. No significant differences are found across genders. Our results are also robust to a number of robustness checks, including a placebo test, where religious affiliation is randomly assigned.

The paper is organised as follows. Section 2 provides a background discussion of the differences between Protestantism and Catholicism in terms of their articles of faith and those differences' implications for entrepreneurship. The data are presented in section 3 , the identification strategy in section 4, and our empirical results and robustness checks, respectively, in sections 5 and 6 . Finally section 7 concludes.

\section{Background}

In this section we compare Catholicism and Protestantism in terms of their basic theological tenets and their key implications for their believers' psychology, work ethic, and position towards mundane success.

\subsection{Catholicism and Protestantism}

Catholicism and Protestantism share the same fundamental articles of faith, but they differ substantially in how religion should be practically lived. According to the thirteenvolume The New Schaff-Herzog Encyclopedia of Religious Knowledge by religious historians Johann Jakob Herzog and Phillip Shaff, Protestantism:

retained from the Roman Catholic system all the objective doctrines of Christianity concerning the Trinity and the divine human character and work of Christ, in fact, all the articles of faith contained in the Apostles' and other ecumenical creeds of the early church. But it joined issue with the prevailing soteriology, that is, the application of the doctrines relating to Christianity [...]. It brought the believer into direct relation and union with Christ as 
the one and all-sufficient source of salvation, and set aside the doctrines of sacerdotal and saintly mediation and intercession. [... From this general principle of Evangelical freedom [...] proceed the three fundamental doctrines of Protestantism - the absolute supremacy of (1) the Word and of (2) the grace of Christ, and (3) the general priesthood of believers. ("Protestantism" in Herzog and Schaff, 1908, vol. IX).

The Protestant Supremacy of the Word states that the scriptures are the only source of faith and establishes the right to individual interpretation. This is in sharp contrast with Catholicism which grounds faith on both the Bible and tradition and makes tradition, especially the decrees of Popes and Councils, the only legitimate interpreter of the Word.

The Protestant supremacy of the grace of Christ affirms that salvation comes only and directly from Christ and that it requires no mediation from the Church or the clergy, so it is a "free" grace. The sinner is saved solely on the grounds of the merits of Christ. In Catholicism, salvation depends instead on both faith and good works, stressing the role of works.

The Protestant universal priesthood of believers states that all Christians have the right and the duty to read the Bible, proclaim it in public, and to take part in the government and all public affairs of the Church. This contrasts with Catholicism, which is based on exclusive priesthood authority, with priests being the necessary mediators between God and the people (Herzog and Schaff, 1908).

The psychology of believers, the work ethic, and the appreciation of worldly success of each confession are all influenced by these principles.

From a psychological perspective, the Catholic should have a more "collectivistic" personality that values social connections and group affiliation, given that Catholicism emphasises the sense of community and group rituality. As a result, Catholics should feel a deep sense of obligation toward the community, which might induce them to subordinate individual desires to the benefit of the collective good Cohen and Hill, 2007 and references therein). Conversely, the principles of personal relation with God and that of being the unique legitimate interpreter of the Scriptures imply that the Protestant should have an individualistic personality, so the Protestant worldview emphasizes personal goals, uniqueness, and personal control (Cohen and Hill, 2007). The Protestant believes in the 
autonomy of his or her conscience, which is the ultimate judge of his or her actions, even if they are in contrast with established political or religious institutions. Protestantism is conducive to self-reflection, research, and investigations and is less inclined to mysticism than Catholicism is.

As regards the work ethic, the two confessions differ markedly. According to the medieval Catholic theology, Christianity is divided into two parts: those who have received the "calling", that is, the devout and the holy, whose life is to be monastic, focused on prayer and meditation and entirely turned to God; and those who have not received the "calling", who must live out their lives as best they can in the secular world (Bonhoeffer, 1959). ${ }^{4}$

In medieval times work was seen as a punishment for man's original sin (Schaltegger and Torgler, 2009). This view has changed over the centuries, but work remains associated with toil and difficulty in the Catholic tradition. Its merit is only that of allowing man to share Christ's suffering on the Cross:

"Sweat and toil, which work necessarily involves in the present condition of the human race, present the Christian and everyone who is called to follow Christ with the possibility of sharing lovingly in the work that Christ came to do" (John Paul II, 1981, Laborem Exercens: Encyclical Letter of the Supreme Pontiff John Paul II on Human Work).

In contrast, Protestantism, in both its streams of Calvinism and Lutheranism, perceives work of whatever kind as honourable, necessary, and a service to God. Luther dismissed the separation between the "called" and others and contended that all persons should see their labour as their vocation; just as some are called to serve God in the religious ministry, others are called to serve God through secular labours, and there is no spiritual distinction between the two (Eaton, 2013). ${ }^{5}$

Catholicism and Protestantism differ also in their attitude towards the worldly success. The monolithic and traditional Catholic Church tends to orient its members toward

\footnotetext{
${ }^{4}$ The superiority of meditation over work derives from the ancient Greeks and Romans, who viewed work as dishonourable. (See, e.g., Canfora, 1989).

${ }^{5}$ Luther's and Calvin's views differed regarding the morality of trade activity. Luther looked at trade as a way to take advantage of the needs of the others, while Calvin considered trade and commerce useful and that those engaged in trade provide a service to society at a risk to themselves.
} 
the hereafter, so successful performance in the marketplace and the acquisition of the symbols of economic achievement are of relatively little importance as an indication of the Catholic's status after death. On the other hand, Protestants are more concerned with worldly success, the attainment of material possession, status, and the prestige that is associated with upward social mobility, since these achievements are often viewed as signals of salvation (Mayer and Sharp, 1962). ${ }^{6}$

Acknowledging these differences, Weber thought that the "communitarian" ethic of the Catholics impeded educational and economic achievement, while the "inner worldly asceticism" of the Protestants, with its emphasis on individual achievement facilitated their success (Greeley, 1989). According to McClelland (1961) the Protestant work ethic's ideas and values determine the practices of teaching independence, delayed gratification and mastery, which lead to strong motivations to achieve. These high achievers are likely to become successful entrepreneurs (Furnham, 1987).

\subsection{Implications for Enterpreneurship}

In summary, the tenets of Protestantism should lead adherent Protestants to be more determined to achieve success, more willing to work hard, more disciplined, and more focused on their own self-realisation than are Catholics. Are these character traits favourable to entrepreneurship? Parker, 2004, 2005 summarises the current state of research on entrepreneurship in economics, pointing out that we still do not have a clear answer to this question. The decision to become an entrepreneur might depend on the individual's exogenously distributed entrepreneurship ability (Lucas, 1978), on the probability that a particular new venture will survive (Holmes and Schmitz, 1990), or on the individual's level of risk aversion, which influences how the trade-off between risk and returns is resolved (Kilhstrom and Laffont, 1979). Character traits might be accommodated by all these models and might contribute to improving the models' assumptions. For instance, the probability of a new venture's survival might depend on individual determination and willingness to succeed, or the individual disposition to work hard might be central in the

\footnotetext{
${ }^{6}$ This is especially the case in Calvinism. According to the Calvinist concept of predestination, God decides a person's salvation or damnation before his or her birth, but it is hidden to the person, who can do nothing to alter his or her fate. Worldly success is regarded as a sign of being among the select group that will be saved from damnation by God (Becker and Woessmann, 2009; Arrunada, 2010).
} 
decision to adopt strategies of self-insurance, such as long hours of work to limit the risk of failure (Parker and Belghitar, 2006).

The purpose of this paper is to provide an empirical answer to whether Protestantism, because of its work ethic, its appreciation of worldly achievements, and its emphasis on individualism, is more favourable to entrepreneurship than Catholicism is.

\section{Data}

We use 5 percent samples of four Swiss censuses carried out every ten years between 1970 and 2000 from the Swiss Federal Statistical Office (FSO, 2013). Data made available by the Integrated Public Use Microdata Series (IPUMS) of the Minnesota Population Center in cooperation with the Swiss Federal Statistical Office include detailed information on respondents' education, occupation, household composition, canton of residence, country of birth, and religious affiliation.

In the sample, which accumulates data from 1970 to 2000 and includes about 1.3 million observations, 89 percent of the Swiss respondents reported being Christian, 6 percent atheist, and 2 percent Muslim. Among the Christians, 52 percent are Roman Catholic and 45 percent are Protestant (i.e., members of the Reformed Church). Other Protestant churches and communities account for another 2 percent, while orthodox Protestants count for 1 percent.

The proportion of Christians dropped from 98 percent in 1970 to 94 percent in 1980, 88 percent in 1990, and 79 percent in 2000. At the same time, the proportion of atheists steadily increased from 1 percent in 1970 to 11 percent in 2000. Similarly the proportion of members of other religions increased from 1 percent in 1970 to 10 percent in 2000 as a result of immigration, especially from Muslim countries.

The proportion of Catholics, Protestants, and atheists, averaged across the sample period between 1970 and 2000, is described in Table 1. In some urban cantons, such as Basel-city, Geneva, and to a lesser extent, Neuchatel, atheism markedly increased in 1990 and 2000 compared to the previous census waves. In most of the other cantons the share of atheists remained at around 5 percent or less, even in the most recent waves. Protestantism and Catholicism are represented in all cantons. In most cases one or the 
other confession clearly prevails. In Argovia, Turgovia, Geneva, Grisons, Basel-Country, and Outer and Inner Rhodes, the distribution is more even.

\section{TABLE 1 AROUND HERE}

In our baseline specification, we define majority Protestant (resp. Catholic) as those Protestants who reside in a canton where at least 60 percent of the residents follow the same religion. We define minority Protestants (resp. Catholic) as Protestants who reside in a canton where less than 25 percent follow the same religion. ${ }^{7}$ Based on these definitions, ten cantons had a Catholic majority coupled with a Protestant minority during the entire period under consideration (Table 1). In only one canton (Bern, the federal capital) was a Protestant majority coupled with a Catholic minority. In a few cantons, the proportions of Protestants and Catholics were close to one of the critical thresholds, as in Shaffausen and Vaud, where there was a Protestant majority only in 1970 that was not accompanied by the Catholic minority. A Catholic minority is found instead in the cantons of Shaffausen and Basel-city in 2000, in the latter case because of the large share of atheists and immigrant followers of other religions. Figures 1 and 2 display the geographical distribution of the two confessions' majorities and minorities. Overall, about 19 percent of the individuals in the sample belong to a Catholic majority, 11 percent to a Protestant majority, about 3 percent (or about 35,000 people) to Catholic minorities and 3 percent to Protestant minorities. In what follows we use the expression religious group to refer to a Catholic or Protestant majority, minority, or intermediate cases.

The geographic and demographic distribution of religious groups does not qualitatively change by altering the thresholds by which they are defined. (The only "swing" canton is Shaffausen, where the proportion of Catholics has been historically very close to the threshold)..$^{8}$

Switzerland has seven geographic entities, to which we refer as regions, defined at the NUTS2 level of aggregation, each of which groups a number of cantons. (Cantons are at the NUTS3 level of aggregation.) These entities do not correspond to administrative units but have purely geographical and historical relevance. Among the seven Swiss regions,

\footnotetext{
${ }^{7}$ We use other thresholds in our robustness section.

${ }^{8}$ Our robustness analysis considers the thresholds of 20 percent,25 percent, and 30 percent for minorities and 55 percent ,60 percent, and 65 percent for majorities.
} 
Espace Mittelland, the largest and the most populous, is composed of the cantons of Bern (the canton seat of the federal capital), Fribourg, Solothurn, Neuchatel, and Jura. Espace Mittelland is the only region that contains all possible religious groups, so receives special attention in our analysis.

\section{TABLE 2 AROUND HERE}

The final sample includes active individuals (both employed and unemployed), aged above 15, born in Switzerland, who report being either members of the Reformed Church (Protestants) or fellows of the Catholic Roman Church (Catholics). ${ }^{9}$

Fellows of other Protestant churches (e.g., the Methodist or the New Apostolic Church), members of other Christian religions, and atheists are dropped. The canton of Basel-city in 1990 and 2000 is also dropped because its proportion of atheists exceeded 30 percent, which is abnormal for Swiss standards. In most of the other cantons the proportion of atheists in these two years remained below 10 percent, while in a few cases it ranged between 10 and 20 percent.

In the end our sample included 443,072 individuals, evenly shared among the four census periods of 1970, 1980, 1990, and 2000.

About 13 percent of the respondents are self-employed, including professionals, entrepreneurs, and other individuals working on their own account. The distribution of the self-employed according to religious denomination, shown in Table 3, reveals no difference in the proportion of entrepreneurs among Catholic and Protestant majorities, while the difference among minorities is almost 5 percentage points. Similar results emerge when we focus only on Espace Mittelland.

\section{TABLE 3 AROUND HERE}

Further summary statistics regarding the respondents' gender, age, native language, marital status, and education are reported in Table 4 by religious group.

\section{TABLE 4 AROUND HERE}

\footnotetext{
${ }^{9}$ The proportion of unemployed in the sample is about 3 percent. We exclude non-native-born individuals from our sample to avoid possible concerns of self-selection, as immigrants could take into account the local areas' distribution of religion when they relocate in the host country.
} 
Overall, the differences across religious groups in terms of age and gender are small. There is some imbalance in respondents' native languages since Protestantism is more frequent among German speakers and less frequent among Italian and, to a smaller extent, French speakers. University degrees and post-secondary technical degrees are more frequent among minorities than among majorities, with only slight differences between the two confessions.

\section{Identification Strategy and the Model}

To identify the effect of Protestant ethics on entrepreneurship, we exploit two facts: 1) an individual's adhesion to religious norms and ethics strengthens as his or her confession's market share decreases and 2) an individual's religion and, in particular, individual membership in a minority or majority confession is exogenously given and depends on intergenerational transmission and the historically determined geographical distribution of religious groups.

Concerning the first point, a major issue that arises in investigating individual adhesion to religious ethics is that self-identification with a certain confession does not necessarily imply internalisation of religious ethical principles, so the implications derived from a simple comparison of individuals' reported affiliations may be misleading. Several religiousness-intensity indicators have been proposed in the literature to resolve this inconsistency (McCleary and Barro, 2006), including the frequency of attendance at religious services, weekly prayers, and donation of money and time to religious organisations, but most are likely to be endogenous to labour market outcomes and cannot be used in our setting.

We propose instead an identification strategy based on the assumption of religious minorities' stronger attachment to religious principles, which rests on at least three justifications. First, according to Bisin and Verdier (2000), Bisin and Verdier (2001), and Bisin, Topa, and Verdier (2004), religion, along with language, history and culture, is an important element of people's identity, which may explain the willingness of minorities to defend their religious identities against the influence of the majority. Second, Stark, 
Finke, and Iannaccone (1995), Finke and Stark (1998), and Stark (1998) suggest that a minority religion's clergy works harder to preserve its followers than does the clergy of a majority religion. Third, given that following a minority religion implies continuous pressure from surrounding dominant religions, membership can be justified only if the attachment to the faith is particularly strong.

Nunziata and Rocco (2014) document the strong attachment of religious minorities to their faiths and show that members of religious minorities in Europe declare themselves to be more religious, are more likely to believe in life after death and heaven and hell, have more confidence in churches, pray more, and pray more regularly than their nonminority counterparts do. In addition, minority Protestants tend to agree more with the principles of the individual's direct and unmediated relationship with God (one tenet of Protestantism) than other Protestants do. As for Catholics, minority Catholics believe more than other Catholics do that salvation can be achieved by means of good works and that individual fate is not predetermined, which is a tenet of Catholicism. Finally, while practically non-existent among majority denominations, transitions from one denomination to another are more frequent among minorities. The pressure of the majority religion selects out the less fervent, leaving only those with strong attachments to their religions in the minority.

As for the second point, that an individual's religion and membership in a minority or majority confession is exogenously given and depends on intergenerational transmission and the historically determined geographical distribution of religious groups, being born in a religious minority in Switzerland can be considered exogenous since the rise and geographical distribution of minorities of both denominations are historically determined. They closely follow the equilibrium found at the end of the religious wars of the sixteenth and seventeenth centuries, which depended mainly on contingent historical conditions. (See the discussion on the history of the Swiss Reformation in Appendix A, as well as in Cantoni, 2010 and Cantoni, 2011). According to Schaff (1882), "since the middle of the sixteenth century the numerical relationship between the two Churches has undergone no material change" (p.118).

This distribution has persisted over the centuries because of the inter-generational transmission of religion within families. (See Nunziata and Rocco, 2014 for a more exten- 
sive discussion on this point related to regions of the former Holy Roman Empire). The historical persistence of the geographical distribution of confessions is evident in the comparison of Figures 3,4, and 5, which depicts Protestant and Catholic areas in Switzerland during the Reformation period (1536), in the seventeenth century, the eighteenth century, and recent years, respectively.

Under the assumption that, conditional to a set of controls, Protestant and Catholic minorities differ only along the ethical dimension, the differential effect of Protestantism versus Catholicism on entrepreneurship can be identified by comparing Protestant and Catholic minorities. ${ }^{10}$

The rationale of our research design is summarised in the diagram in Figure 6. The probability that an individual will be an entrepreneur is measured on the vertical axis, and the degree of adhesion to a religious ethic lies on the horizontal axis. The degree of adhesion is a latent variable that is not directly observed, but the market share of the denomination to which each individual belongs, which is inversely related to the average degree of adhesion to the religion's ethical principles, is observed.

\section{FIGURES 6 AROUND HERE}

In Figure 6, when the degree of adhesion is zero, the likelihood that an individual chooses to be self-employed is independent of religious ethics, whatever the religious affiliation. In this case, the reported religious affiliation is merely a label that carries no specific religious or ethical content. As the degree of adhesion increases, how Protestantism and Catholicism influence entrepreneurship differs, and the full differential effect of Protestant ethics is found between individuals with maximum religious attachment. ${ }^{11}$

Since the individual's degree of adhesion is not observable, we turn to minorities or majorities in order to make an inference, as we expect to find large proportions of individuals with strong attachments to their faiths in the minorities. Thus, by comparing Protestant and Catholic minorities, we are comparing people with high degrees of adhesion on average. If any differential effect of Protestantism exists, it should emerge from

\footnotetext{
${ }^{10}$ For further reading, Nunziata and Rocco (2014) provide ample evidence in support of the comparability of religious minorities.

${ }^{11}$ The relationship between entrepreneurship and religious attachment is assumed to be linear for exposition purposes only, but linearity is not required.
} 
this comparison. Conversely, since religious majorities are likely to include more individuals with lower attachment to religion, the differential effect of Protestantism versus Catholicism among majorities should be small or absent.

Therefore, we estimate the following model:

$$
\text { self } f_{i c t}=\pi_{0}+\pi_{1} P_{i c t}+\pi_{2} M_{i c t}+\pi_{3} m_{i c t}+\pi_{4} M \times P_{i c t}+\pi_{5} m \times P_{i c t}+X_{i c t} \beta+\varepsilon_{i c t}
$$

where self is the condition of self-employment of individual $i$ residing in canton $c$ at time $t ; P$ is a dummy that takes the value of 1 if $i$ is Protestant and 0 if $i$ is Catholic; $M$ and $m$ are dummies that take the value of 1 if $i$ belongs to any majority confession or any minority confession, respectively; ${ }^{12}$ and $M \times P$ and $m \times P$ are interactions between the majority/minority dummies and the Protestant dummy. The vector $X$ includes the individual-level controls of age, gender, education level, native language, and marital status, as well as canton controls (activity rate and the proportion of active people involved in agriculture) and region-by-time fixed effects. ${ }^{13}$ The error term $\varepsilon_{i c t}$ is allowed to be clustered within each canton.

The difference in the propensity for entrepreneurship among Protestant and Catholic minorities, conditional to $X$, is our quantity of interest and can be written as:

$$
E\left(\operatorname{self}_{i c t} \mid P_{i c t}=1, m_{i c t}=1, X_{i c t}\right)-E\left(s e l f_{i c t} \mid P_{i c t}=0, m_{i c t}=1, X_{i c t}\right)=\pi_{1}+\pi_{5}
$$

We refer to it as the effect of Protestantism on entrepreneurship or the effect of Protestantism. The difference in the propensity for entrepreneurship among Protestant and Catholic majorities, conditional to $X$, can be written as:

$$
E\left(\text { self }_{i c t} \mid P_{i c t}=1, M_{i c t}=1, X_{i c t}\right)-E\left(\text { self } f_{i c t} \mid P_{i c t}=0, M_{i c t}=1, X_{i c t}\right)=\pi_{1}+\pi_{4}
$$

\footnotetext{
${ }^{12}$ More precisely these dummies take the value of 1 if the market share of individual $i$ 's religion in $i$ 's canton or residence at time $t$ is larger than 60 percent or smaller than 25 percent, respectively. The majority/minority dummies vary at the individual level since they depend on the individual's particular religion. See the robustness checks in section 6 for results that adopt alternative thresholds and an alternative model specification.

${ }^{13}$ Including canton effects would imply a problem of almost perfect multicollinearity because only Bern's Protestant majority and Catholic minority are persistent. Shaffhausen and Vaud, two small cantons, have a Protestant majority only in 1970. If the observations corresponding to the latter cantons in 1970 were dropped, the canton dummy corresponding to Bern could be obtained by combining the $M \times P$ and $(m-m \times P)$ dummies, the latter being equivalent to the Catholic minority dummy.
} 
This quantity represents a specification test statistic for our theory. Since our model predicts that there is little internalisation of ethical principles among majorities, we should observe little or no difference between the propensity for entrepreneurship between Protestant and Catholic majorities. In the following we refer to this quantity as the specification test.

\section{Empirical Results}

Table (5) reports our main results, that is, the effect of Protestantism on entrepreneurship and the specification test obtained when model (1) is estimated on four alternative samples. ${ }^{14}$

Column (1) shows the full sample estimation, our baseline case, while column (2) refers to Espace Mittelland, the only region where all religious groups can be simultaneously observed and we can estimate our effect of interest within a smaller and even more homogeneous area. Column (3) focuses on German-speaking residents only in order to filter out broad cultural traits that might differ among linguistic communities. Finally, column (4) drops the cantons of Basel-city and Geneva from the sample because of their relatively high proportion of atheists. In all cases we find that Protestantism increases the propensity for entrepreneurship by an amount between 2.3 percent and 4.4 percent. This is a sizeable effect considering that 13 percent of individuals in Switzerland are self-employed. The specification test, given by the difference in the propensity for entrepreneurship between Protestant and Catholic majorities, always displays estimates that are not significantly different from zero. In other words, religious ethics affect entrepreneurship only among minorities, that is, those who adhere closely to their confessions' ethical principles. No significant differences emerge when considering individuals whose attachment to their confession is weak.

\section{TABLE 5 AROUND HERE}

Tables (6) and (7) estimate the model displayed in Table (5) but focus on the selfemployed in high-ranking occupations and the self-employed in low-ranking occupations,

\footnotetext{
${ }^{14}$ Appendix B provides a table of all main estimated coefficients.
} 
respectively. According to the ISCO88 classification, we define legislators, managers, professionals, technicians and associate professionals, and skilled agricultural occupations as high-ranking occupations and low-ranking occupations as service work and elementary occupations.

We find that Protestantism increases the propensity for entrepreneurship only in the high-ranking occupations, which is in line with the main difference between Protestantism's and Catholicism's work ethic - that is, the emphasis on individuals' achievements. In this case, too, our specification tests always pass.

\section{TABLES 6 AND 7 AROUND HERE}

\section{Robustness Checks}

\section{(A) Placebo Test}

An important concern regarding the validity of our results is that the model may not pick up the effect of religious ethics so much as the effect of some confounding factor, such as the characteristics of the territories where the religious groups reside, which could be more or less favourable to entrepreneurship. We partly address this issue by focusing on Espace Mittelland, a relatively homogeneous region that hosts all religious groups.

To determine whether the effect of Protestantism on entrepreneurship is spurious, we performed a placebo test as well, which randomly reshuffles individual religious affiliation for each canton and year. This reshuffling preserves the market shares of the religions and does not alter the geographic distribution of majorities and minorities that is given. We have estimated model (1) on the reshuffled data and checked to see whether a significant effect of religion resulted, which would indicate that the effect we found is due to confounders, not to religion. We repeated this operation 500 times, and the effect of Protestantism was significantly different from zero only ten time, that is, in 2 percent of the repetitions. We then repeated the placebo test, focusing on Espace Mittelland and on the sample of German-speaking respondents only and found a significant effect of Protestantism in less than 1 percent and less than 3 percent of the repetitions, respectively. Therefore, in all cases we can reject the possibility of a spurious effect. 


\section{(B) Alternative Minority and Majority Thresholds}

A second possible controversy lies in the definition of minorities and majorities. As a robustness check, Table 8 reproduces the baseline estimate by changing the thresholds to 55 percent, 60 percent, and 65 percent for majorities and 20 percent, 25 percent, and 30 percent for minorities. Our results remained remarkably stable across all definitions.

\section{TABLE 8 AROUND HERE}

\section{(C) Alternative Parametric Specification}

To avoid specifying minority and majority thresholds altogether, we considered the following alternative model specification:

$$
\operatorname{self}_{i c t}=\pi_{0}+\pi_{1} P_{i c t}+\pi_{2} S_{i c t}+\pi_{3} P_{i c t} \times S_{i c t}+X_{i c t} \beta+\varepsilon_{i c t}
$$

For this model, besides the usual Protestant vs Catholic dummy $P_{i c t}$, we included $S_{i c t}$, which is the market share of individual $i$ 's religion in canton $c$ at time $t$, and the interaction between the two. Based on our theory, we should observe a decline in the effect of Protestantism compared to Catholicism as $S_{i c t}$ increases, and this prediction is confirmed by the estimates. The effect of Protestantism is given by:

$$
\begin{array}{r}
E\left(\text { self }_{i c t} \mid P_{i c t}=1, S_{i c t}=s, X_{i c t}\right)-E\left(\operatorname{sel} f_{i c t} \mid P_{i c t}=0, S_{i c t}=s, X_{i c t}\right)= \\
=\pi_{1}+\pi_{3} s=0.0247-0.0368 s
\end{array}
$$

which is significantly different from zero for all $s<0.49$. The point estimate at $s=0.49(0.0066)$ is very small, while it is 0.015 at $s=0.25$ and 0.021 at $s=0.10$.

\section{(D) Secularization Structural Breaks and Age Brackets}

Table 9 shows the results of separately estimating model (1) for the periods 1970-1990 and 2000 in order to distinguish the pre-secularisation phase from that characterised by more marked secularisation and an increase in atheism. No major differences emerge 
compared to the baseline results. The table also analyses separately individuals of age 15-30 and those above $30 .{ }^{15}$

We find that the effect of Protestantism is statistically significant among the older group only. Finally, we report estimates for females and males above 30 years of age and find that the point estimate is larger for males than for females, but the difference is not statistically significant.

\section{(E) Former Holy Roman Empire Regions Estimates}

Finally, in a companion paper (Nunziata and Rocco, 2014) we use European Social Survey data to estimate the same model on the regions of the former Holy Roman Empire, i.e. Austria, Belgium, the Czech Republic, Germany, Luxemburg, Slovenia, Trentino, the eastern part of France, and the western Polish regions of Pomerania, Lubuskie, and Dolnoslaskie. Similarly to Switzerland, religious traditions in the former Holy Roman Empire are historically determined as a result of the establishment of the "cuius regio eius religio" (whose realm, his religion) rule, which granted the rulers the right to decide the official and unique religion of their territories after the Peace of Augsburg in 1555. After analysing the geographical persistence of religious majorities and minorities in these regions, we estimate similar coefficients, even when we restrict the sample to German regions. Our estimated effects range between 3.6 percent (whole former Holy Roman Empire sample) and 5.5 percent (German regions only).

\section{TABLE 9 AROUND HERE}

\section{Conclusions}

This paper presents a novel methodology with which to determine the causal effect of religious ethics on economic behaviour by investigating the implications of Protestantism versus Catholicism on entrepreneurship. We adopted a quasi-experimental research design on Swiss data based on the minority status of religious denominations across Swiss cantons, exploiting the assumption that religious minorities have a strong degree of attachment to religious ethics than do religious majorities.

\footnotetext{
${ }^{15}$ About 10 percent of the self-employed are 15 -30 years of age.
} 
The focus on Switzerland is motivated by its comparatively small size and homogeneous economic environment; its variety of combinations of Protestant and Catholic minorities and majorities; the confessions' geographical distribution, which reflects an historically determined equilibrium; the homogeneous ethical principles of Swiss Protestantism since it historically derives from the Zwinglian branch in the German-speaking cantons and the affine Calvinist branch in the French-speaking cantons.

We find that that religious ethics play a significant role in explaining economic outcomes, with Protestants being 2.3 to 4.4 percentage points more likely than Catholics to be entrepreneurs. These results stand after controlling for individual-level socio-economic characteristics (including education), economic development, and sectoral composition, as well as institutions at the cantonal and regional level. They are also robust across alternative specifications and to a number of robustness checks, including a placebo test. We find no effect when Protestant and Catholic majorities are compared, suggesting that the implications of religious ethical norms on economic outcomes emerge only when such norms are fully internalized, as they tend to be among minority religions. Protestantism is found to significantly affect the probability that an individual will be self-employed, but only in high-ranking occupations and only for individuals older than age 30 . We find no differential effect across genders.

Overall, our analysis shows that religious ethical principles may influence individual behaviour in the economic domain, providing empirical evidence in support of Weber (1904)'s original thesis. 


\section{References}

Arrunada, B. (2010): "Protestants and Catholics: Similar Work Ethic, Different Social Ethic," Economic Journal, 120, 890-918.

Becker, S., and L. Woessmann (2009): "Was Weber Wrong? A Human Capital Theory of Protestant Economic History," The Quarterly Journal of Economics, 124(2), 531-596.

Bisin, A., G. Topa, And T. Verdier (2004): "Religious Intermarriage and Socialization in the United States," Journal of Political Economy, 112(3), 615-664.

Bisin, A., And T. Verdier (2000): "Beyond The Melting Pot: Cultural Transmission, Marriage, And The Evolution Of Ethnic And Religious Traits," Quarterly Journal of Economics, 115(3), 955-988.

(2001): "The economics of cultural transmission and the dynamics of preferences," Journal of Economic Theory, 97, 298-319.

Bonhoeffer, D. (1959): The cost of discipleship. Collier Books, New York.

CANFora, L. (1989): Una società premoderna. Lavoro, morale, scrittura in Grecia. Dedalo.

Cantoni, D. (2010): "The economic effects of the Protestant Reformation: Testing the Weber hypothesis in the German Lands," Discussion paper, Economics Working Papers 1260, Department of Economics and Business, Universitat Pompeu Fabra.

(2011): "Adopting a new religion: The case of Protestantism in 16th Century Germany," Economics Working Papers 1265, Department of Economics and Business, Universitat Pompeu Fabra.

Cohen, A., And P. Hill (2007): "Religion as Culture: Religious Individualism and Collectivism Among American Catholics, Jews, and Protestants," Journal of Personality, 75(4), 709-742. 
Cuervo, A. (2005): "Individual and Environmental Determinants of Entrepreneurship," International Entrepreneurship and Management Journal, 1, 293-311, 10.1007/s11365005-2591-7.

EAton, D. (2013): "The Economists of the Reformation: An Overview of Reformation Teaching Concerning Work, Wealth, and Interest," SAGE Open, pp. 1-9.

Finke, R., And R. Stark (1998): "Reply to Olson: Religious choice and competition," American Sociological Review, 63, 761-766.

FSO (2013): Swiss Census. Minnesota Population Center. Integrated Public Use Microdata Series, International: Version 6.2.

Furnham, A. (1987): "The protestant work ethic: a review of the psychological literature," European Journal of Social Psychology, 14, 87-104.

Greeley, A. (1989): "Protestant and Catholic: Is the Analogical Imagination Extinct?," American Sociological Review, 54(4), 485-502.

Herzog, J. J., and P. Schaff (1908): The New Schaff-Herzog Encyclopedia of Religious Knowledge. Funk and Wagnalls Company.

Holmes, T. J., And J. A. Schmitz (1990): "A theory of entrepreneurship and its application to the study of business transfers," Journal of Political Economy, 87, 265294.

John Paul II (1981): Laborem Exercens: Encyclical Letter of the Supreme Pontif John Paul II on Human Work. Catholic Truth Society.

Kilhstrom, R. E., And J. LAFFont (1979): "A general equilibrium entrepreneurial theory of firm formation based on risk aversion," Journal of Political Economy, 87, $719-749$.

LucAs, R. (1978): "On the size distribution of business firms," Bell Journal of Economics, 9, 508-523.

Mayer, A., And H. Sharp (1962): "Religious Preference and Worldly Success," American Sociological Review, 27(2), 218-227. 
MCCleary, R. M., And R. J. BARro (2006): "Religion and Economy," Journal of Economic Perspectives, 20(2), 49-72.

McClelland, D. (1961): The Achieving Society. D. Van Nostrand, reprinted in 2010 by Martino Fine Books, New York.

Meyer, H. (1976): Der zweite kappeler Krieg: Die Krise der schweizerischen Reformation. Hans Rohr, Zurich.

Nunziata, L., And L. Rocco (2014): "The Protestant Ethic and Entrepreneurship: Evidence from Religious Minorities in the Former Holy Roman Empire," Discussion Paper 53566, MPRA.

PARKer, S. (2005): "“The Economics of Entrepreneurship: What We Know and What We Don't," Foundations and Trends in Entrepreneurship, 1(1), 1-54.

PARKer, S., And Y. Belghitar (2006): "What happens to nascent entrepreneurs? An econometric analysis of the PSED," Small Business Economics, 27, 81-101.

PARKer, S. C. (2004): The Economics of Self-Employment and Entrepreneurship. Cambridge University Press, Cambridge, MA.

Renneboog, L., and C. Spaenjers (2012): "Religion, Economic Attitudes, and Household Finance," Oxford Economic Papers, 64(1).

Schaff, P. (1882): History of the Christian Church. Vol. VIII: Modern Christianity. The Swiss Reformation. Grand Rapids, MI: Christian Classics Ethereal Library.

Schaltegger, C., And B. Torgler (2009): "Work ethic, protestantism and human capital," Economics Letters, 107(2), 99-101.

Sheldon, H. (1984): History of the Christian Church. Vol. III The modern Church. Thomas Y. Crowell \& Co, New York.

Stark, R. (1998): "Catholic contexts: Competition, commitment and innovation," Review of Religious Research, 39, 197-208. 
Stark, R., R. Finke, and L. IAnnaccone (1995): "Pluralism and piety: England and Wales, 1851," American Sociological Review, 34, 431-444.

TAWney, R. H. (1926): Religion and the rise of capitalism. Mentor Books, New York, NY.

Weber, M. (1904): The Protestant Ethic and the Spirit of Capitalism, vol. reprinted 2001. Roxbury Publishing Company. 
Figure 1: Protestant Residents

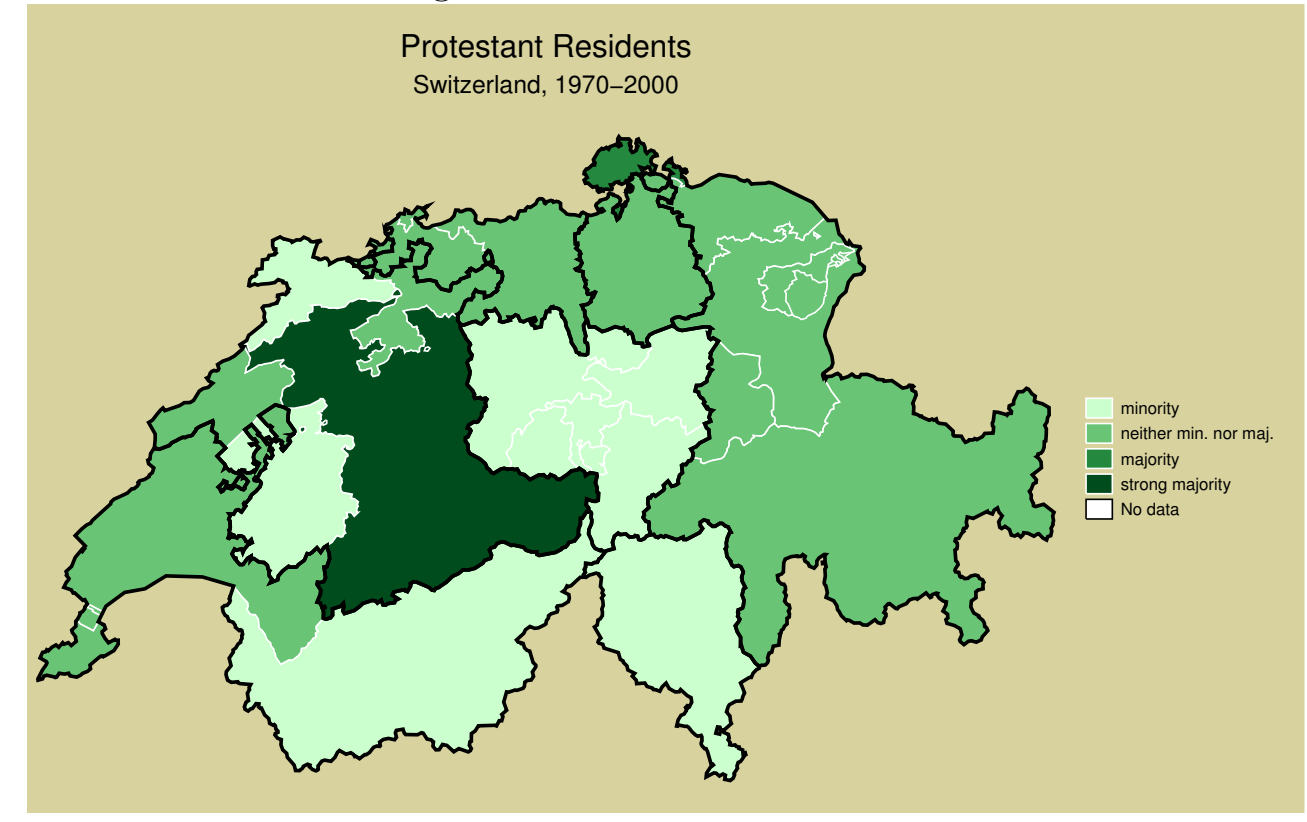

NUTS 3 
Figure 2: Catholic Residents

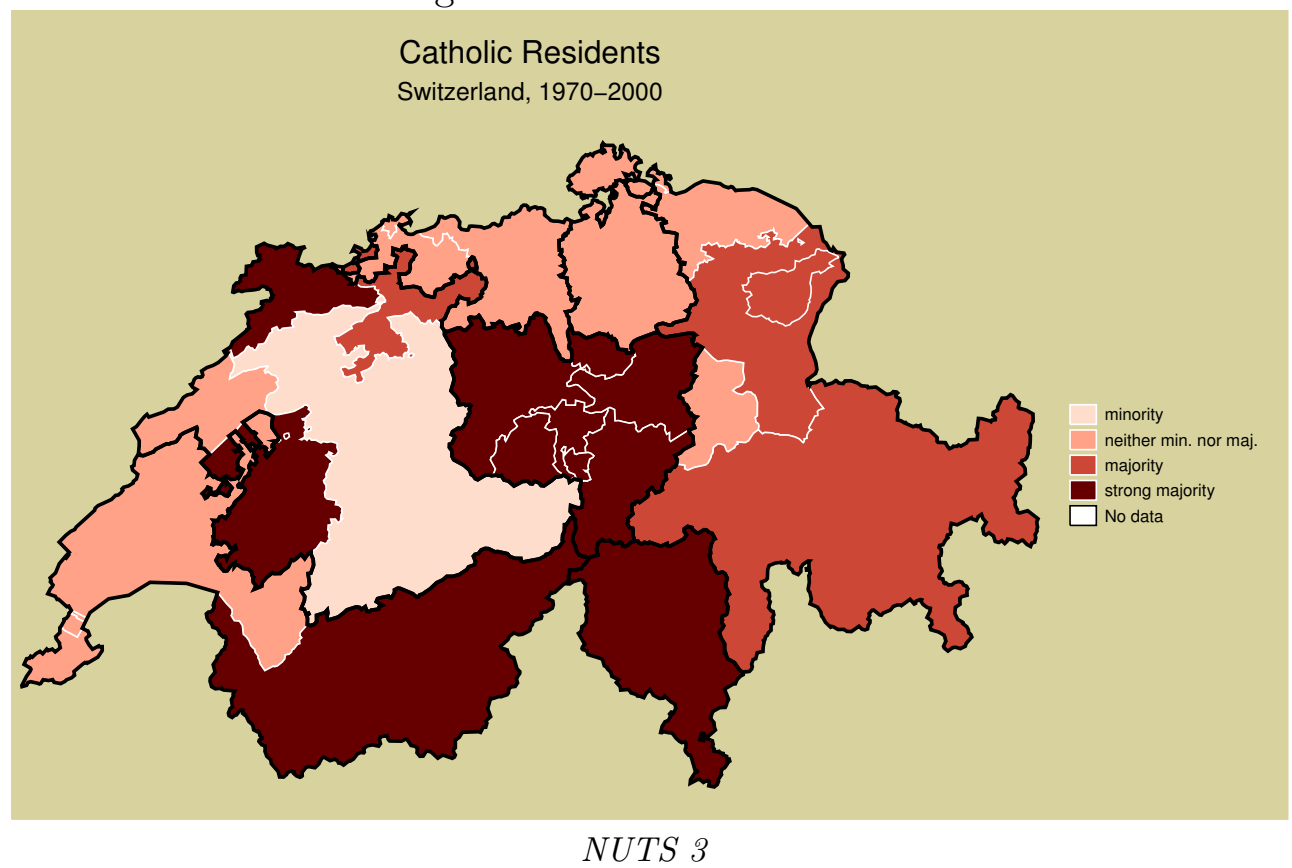

Figure 3: Geographical Distribution of Confessions in the Old Swiss Confederacy during the Reformation period (1536)

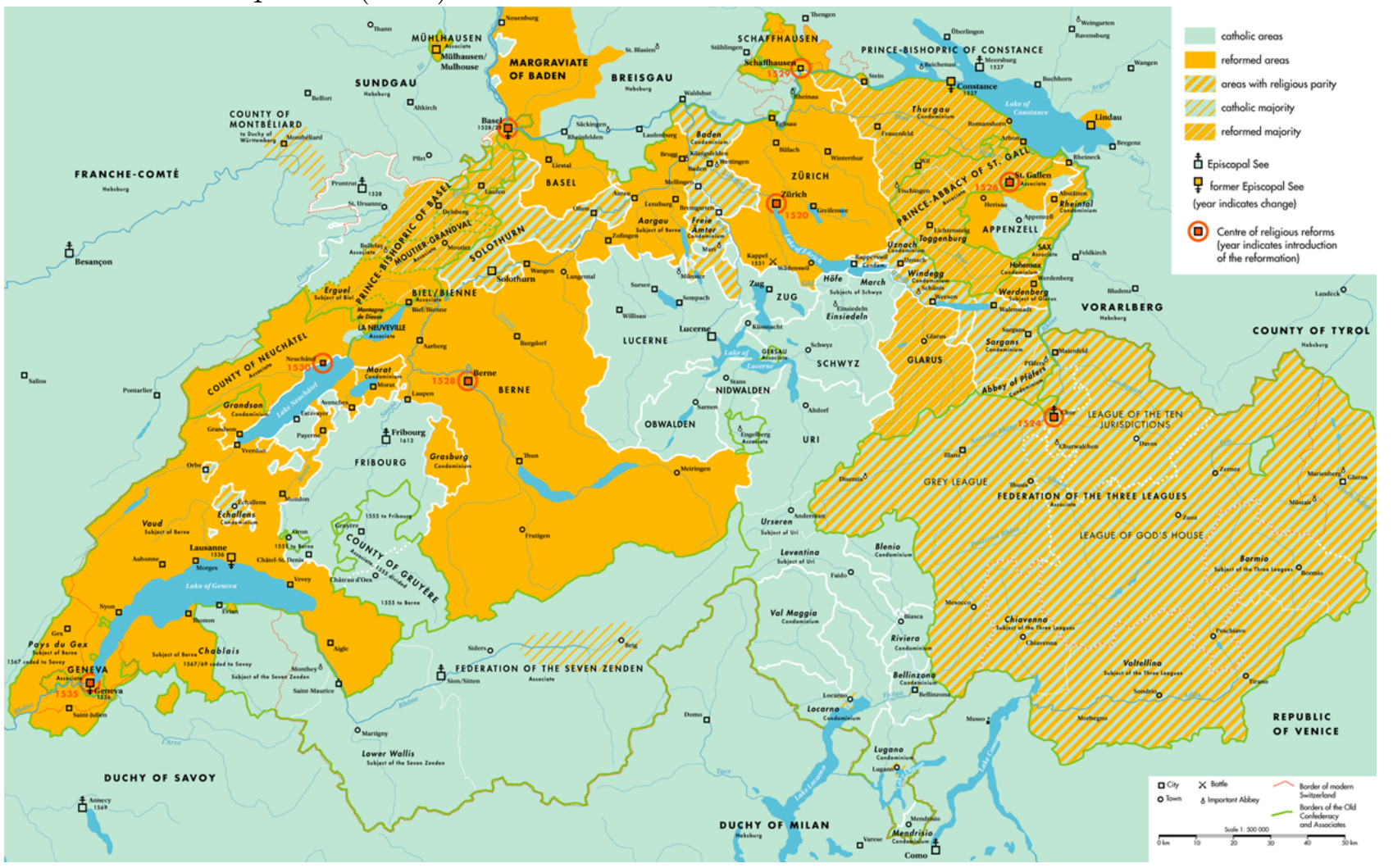

Source: Marco Zanoli based on Putzger Historischer Weltatlas, Schweizer Ausgabe, Cornelsen Verlag, 2004. 
Figure 4: Geographical Distribution of Confessions in the Old Swiss Confederacy in 17th and 18 th century

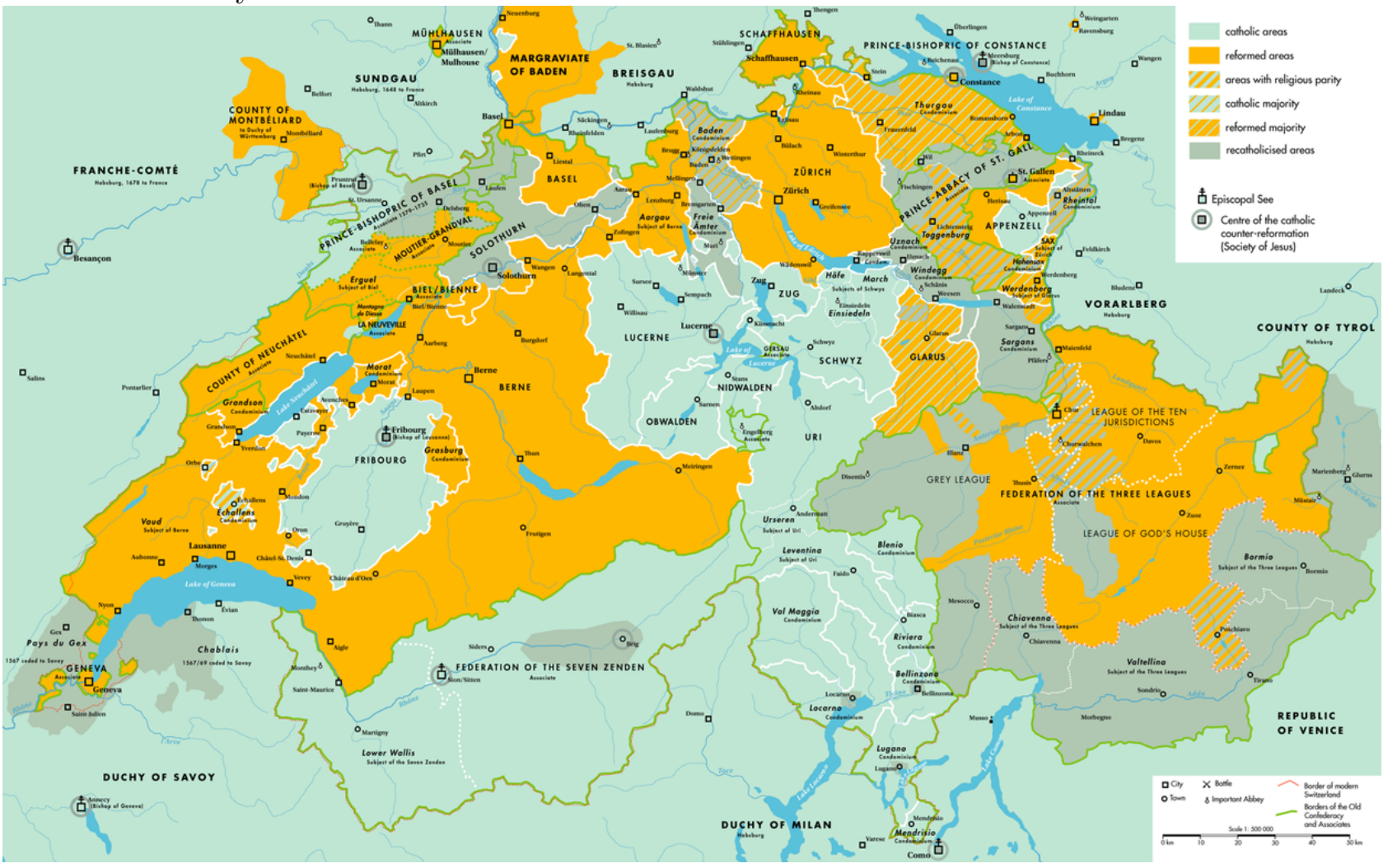

Source: Marco Zanoli based on Putzger Historischer Weltatlas, Schweizer Ausgabe, Cornelsen Verlag, 2004 . 
Figure 5: Geographical Distribution of Confessions in the Swiss Confederation in 2000

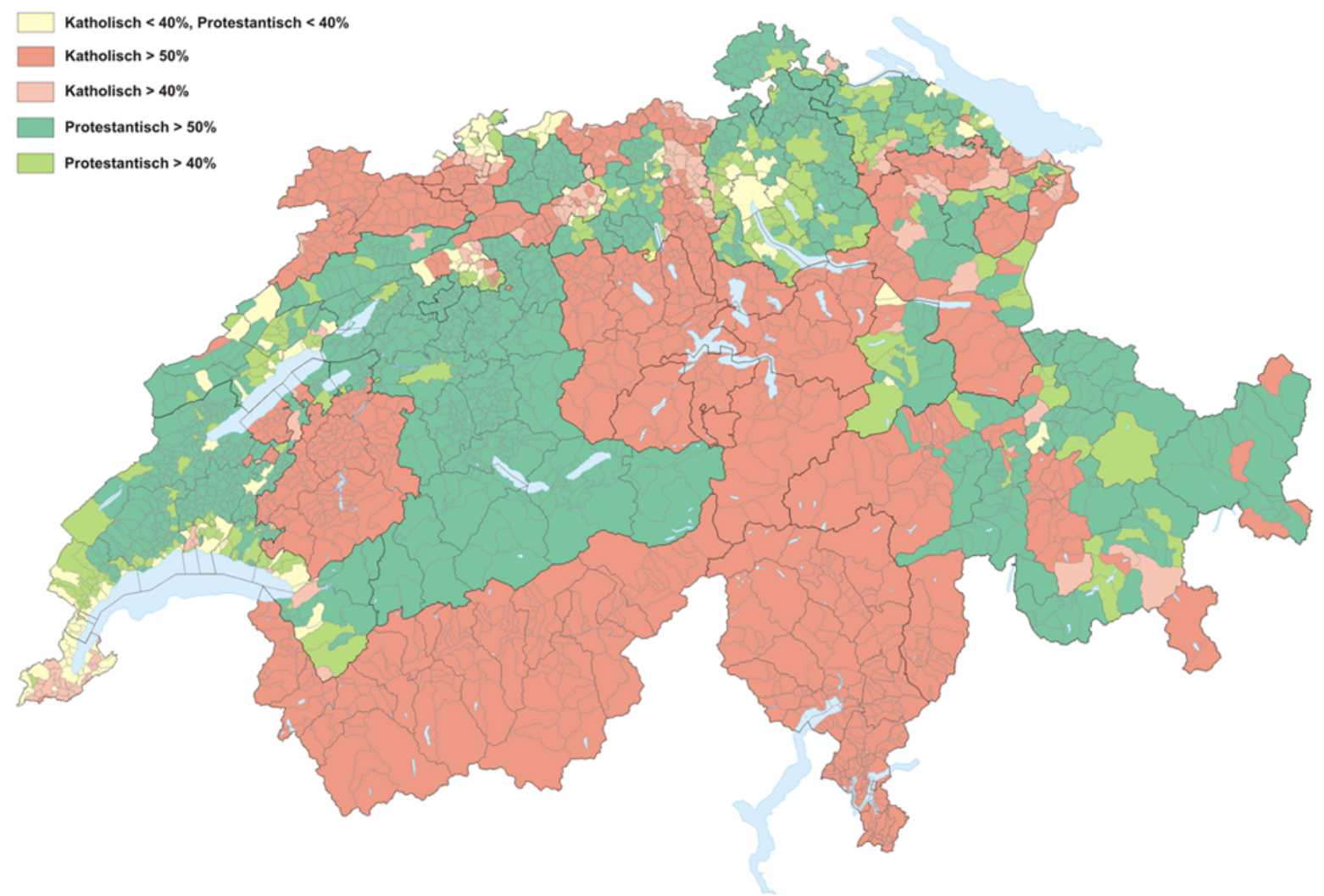

Source: Swiss Federal Statistical Office.

Figure 6: The propensity of being an entrepreneur and the degree of adhesion to Protestantism and Catholicism

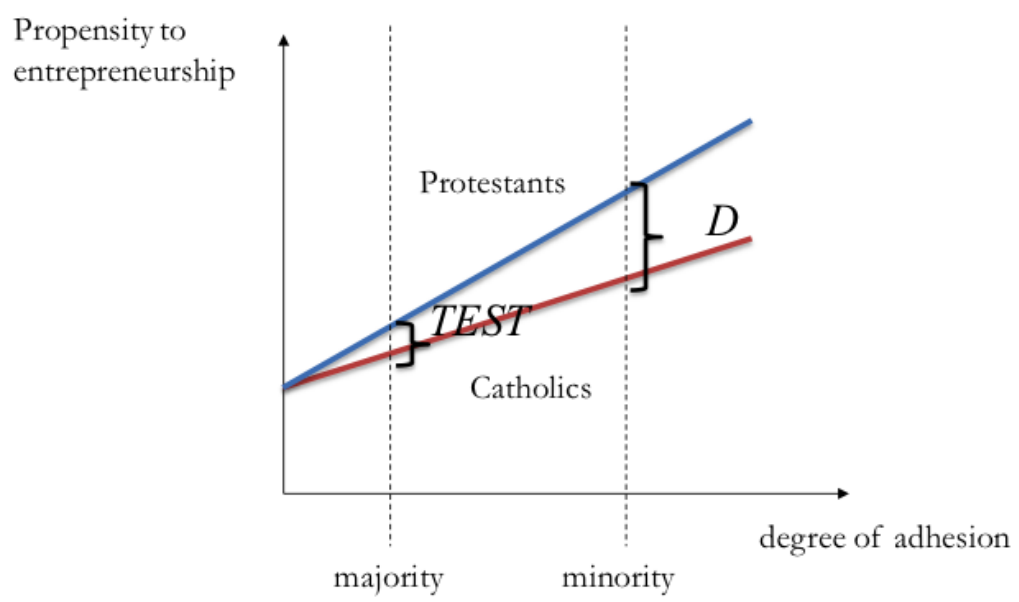


Table 1: Catholic and Protestants in Swiss Cantons

\begin{tabular}{lccc}
\hline & Catholic & Protestant & atheist \\
\hline Zurich & 0.34 & 0.50 & 0.07 \\
Bern & 0.17 & 0.73 & 0.04 \\
Luzern (Lucerne) & 0.79 & 0.12 & 0.03 \\
Uri & 0.90 & 0.06 & 0.01 \\
Schwyz & 0.82 & 0.10 & 0.02 \\
Obwalden (Obwald) & 0.89 & 0.06 & 0.02 \\
Nidwalden (Nidwald) & 0.82 & 0.11 & 0.03 \\
Glarus & 0.40 & 0.50 & 0.03 \\
Zug & 0.71 & 0.17 & 0.04 \\
Fribourg & 0.79 & 0.14 & 0.03 \\
Solothurn & 0.52 & 0.34 & 0.07 \\
Basel-Stadt (Basel-City) & 0.32 & 0.39 & 0.19 \\
Basel-Landschaft (Basel-Country) & 0.37 & 0.47 & 0.08 \\
Schaffhausen & 0.28 & 0.55 & 0.08 \\
Outer and Inner Rhodes & 0.42 & 0.47 & 0.03 \\
St. Gallen (St. Gall) & 0.59 & 0.31 & 0.03 \\
Graubundun (Grisons) & 0.50 & 0.43 & 0.02 \\
Aargau (Argovia) & 0.45 & 0.41 & 0.05 \\
Thurgau (Thurgovia) & 0.40 & 0.48 & 0.03 \\
Ticino & 0.84 & 0.07 & 0.04 \\
Vaud & 0.36 & 0.49 & 0.08 \\
Valais & 0.89 & 0.05 & 0.02 \\
Neuchatel & 0.36 & 0.47 & 0.11 \\
Geneva & 0.48 & 0.26 & 0.15 \\
Jura & 0.81 & 0.12 & 0.03 \\
\hline Total & 0.46 & 0.40 & 0.06 \\
\hline
\end{tabular}


Table 2: Religious Majorities and Minorities

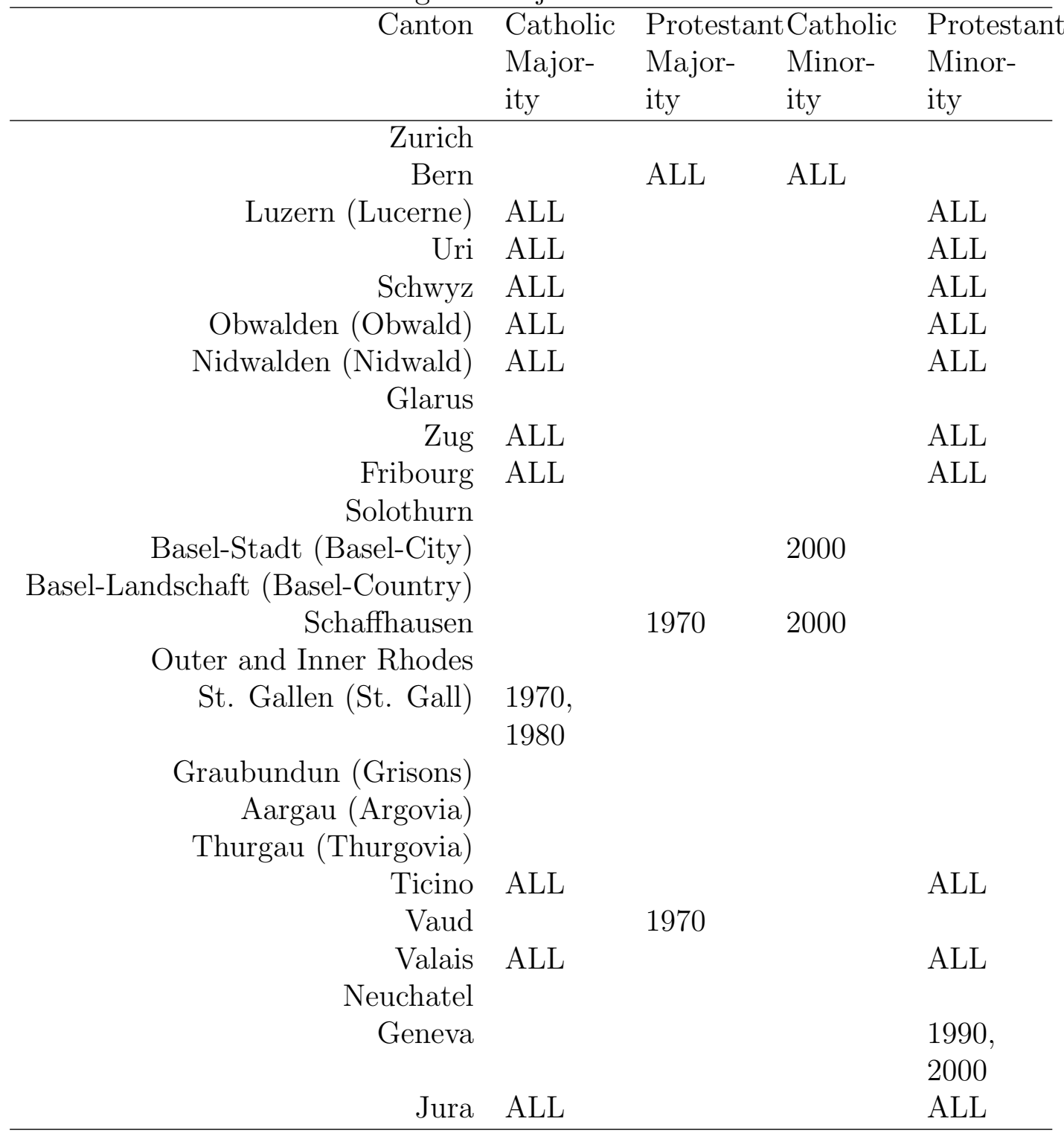

Table 3: The Sample

\begin{tabular}{|c|c|c|c|c|c|c|c|c|}
\hline & \multirow{2}{*}{$\begin{array}{l}\text { self- } \\
\text { employed }\end{array}$} & \multirow[b]{2}{*}{$\begin{array}{l}\text { Catholic } \\
\text { niether } \\
\text { major- } \\
\text { ity nor } \\
\text { minor- } \\
\text { ity }\end{array}$} & \multicolumn{2}{|c|}{ ProtestantCatholic } & \multicolumn{2}{|c|}{ ProtestantCatholic } & \multirow{2}{*}{$\begin{array}{l}\text { Protestant } \\
\text { Minor- } \\
\text { ity }\end{array}$} & \multirow{2}{*}{ Total } \\
\hline & & & $\begin{array}{l}\text { niether } \\
\text { major- } \\
\text { ity nor } \\
\text { minor- } \\
\text { ity }\end{array}$ & $\begin{array}{l}\text { Major- } \\
\text { ity }\end{array}$ & $\begin{array}{l}\text { Major- } \\
\text { ity }\end{array}$ & $\begin{array}{l}\text { Minor- } \\
\text { ity }\end{array}$ & & \\
\hline \multirow[t]{4}{*}{ Switzerland } & $\mathrm{NO}$ & 96,010 & 130,322 & 80,430 & 57,527 & 8,827 & 11,964 & 385,080 \\
\hline & YES & 12,148 & 19,405 & 13,766 & 9,838 & 895 & 1,940 & 57,992 \\
\hline & $\%$ & 11.2 & 13.0 & 14.6 & 14.6 & 9.2 & 13.9 & 13.1 \\
\hline & Total & 108,158 & 149,727 & 94,196 & 67,365 & 9,722 & 13,904 & 443,072 \\
\hline \multirow[t]{4}{*}{ Esp. Mittelland } & $\mathrm{NO}$ & 11,353 & 11,821 & 14,532 & 51,066 & 8,580 & 2,631 & 99,983 \\
\hline & YES & 1,337 & 1,645 & 2,374 & 8,696 & 862 & 506 & 15,420 \\
\hline & $\%$ & 10.5 & 12.2 & 14.0 & 14.5 & 9.1 & 16.1 & 13.4 \\
\hline & Total & 12,690 & 13,466 & 16,906 & 59,762 & 9,442 & 3,137 & 115,403 \\
\hline
\end{tabular}


Table 4: Summary Statistics

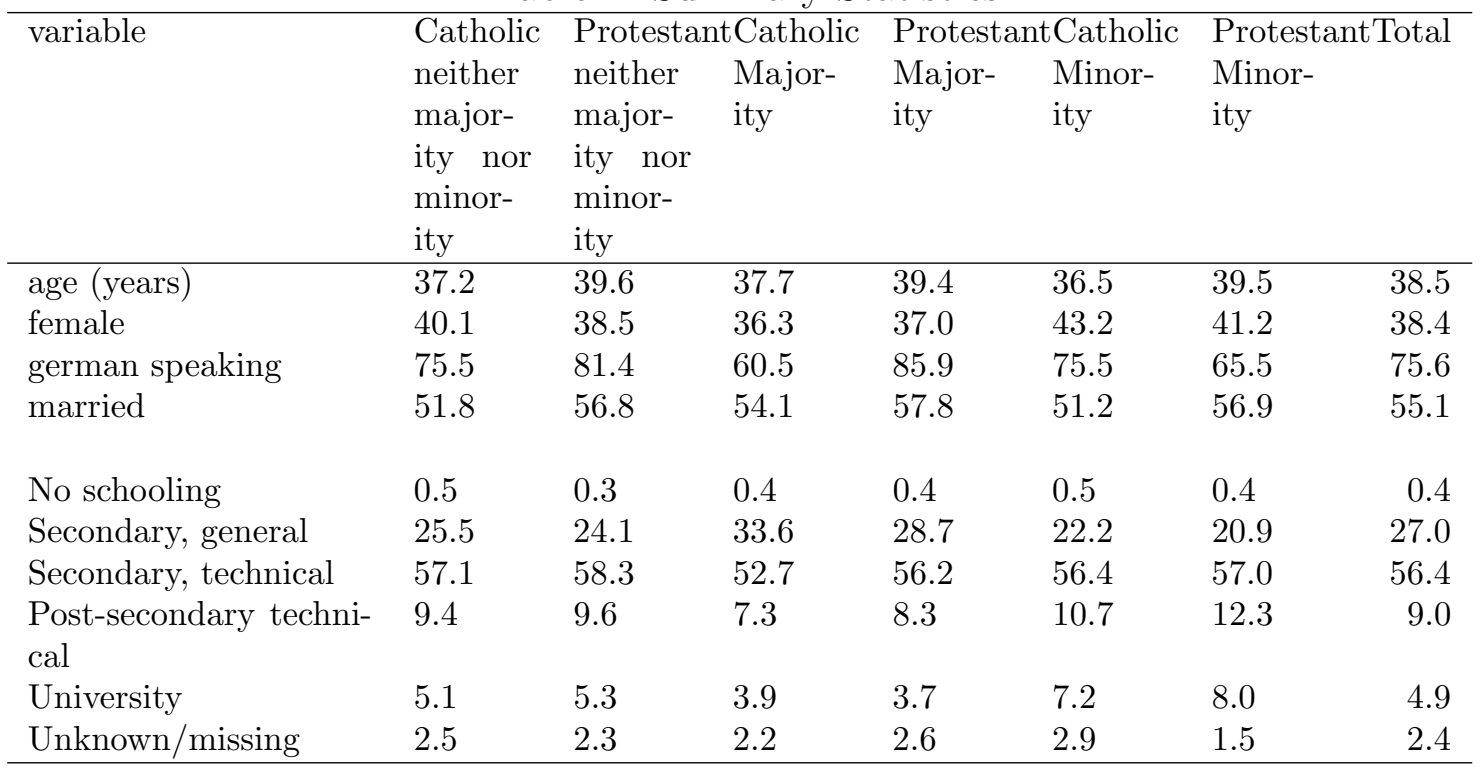

Table 5: Religion and Entrepreneurship - Baseline Model

\begin{tabular}{lllll}
\hline & Baseline & $\begin{array}{l}\text { only Esp. } \\
\text { Mittel- } \\
\text { land }\end{array}$ & $\begin{array}{l}\text { Only } \\
\text { German } \\
\text { speakers }\end{array}$ & $\begin{array}{l}\text { w/o } \\
\text { Basel- } \\
\text { city and } \\
\text { Geneva }\end{array}$ \\
\hline $\begin{array}{l}\text { Min Prot - Min } \\
\text { Cath }\end{array}$ & $0.029^{* * *}$ & $0.044^{* * *}$ & $0.023^{* *}$ & $0.028^{* * *}$ \\
Maj Prot - Maj & $(0.008)$ & $(0.011)$ & $(0.011)$ & $(0.008)$ \\
Cath & -0.006 & 0.002 & -0.002 & -0.006 \\
Obs & $(0.006)$ & $(0.013)$ & $(0.005)$ & $(0.005)$ \\
R2 & 443072 & 115403 & 334436 & 426374 \\
\hline
\end{tabular}

Dependent variable: dummy variable equal to one if respondent is an entrepreneur. Robust standard errors in parentheses. $\mathrm{p}<0.10,{ }^{* *} \mathrm{p}<0.05,{ }^{* * *} \mathrm{p}<0.01$.

Table 6: High Skilled Self Employed

\begin{tabular}{lllll}
\hline & Baseline & $\begin{array}{l}\text { only Esp. } \\
\text { Mittel- } \\
\text { land }\end{array}$ & $\begin{array}{l}\text { Only } \\
\text { German } \\
\text { speakers }\end{array}$ & $\begin{array}{l}\text { w/o } \\
\text { Basel- } \\
\text { city and } \\
\text { Geneva }\end{array}$ \\
\hline $\begin{array}{l}\text { Min Prot - Min } \\
\text { Cath }\end{array}$ & $0.030^{* * *}$ & $0.053^{* * *}$ & $0.021^{*}$ & $0.030^{* * *}$ \\
Maj Prot - Maj & $(0.008)$ & $(0.008)$ & $(0.011)$ & $(0.008)$ \\
Cath & -0.002 & 0.002 & 0.001 & -0.002 \\
Obs & $(0.005)$ & $(0.012)$ & $(0.004)$ & $(0.004)$ \\
R2 & 421653 & 109782 & 318316 & 405628 \\
\hline $\begin{array}{l}\text { Dependent variable: dummy variable equal to one if respondent } \\
\text { is an entrepreneur. Robust standard errors in parentheses. * }\end{array}$ \\
p $<0.10,{ }^{* *}$ p $<0.05,{ }^{* * *}$ p $<0.01$.
\end{tabular}


Table 7: Low Skilled Self Employed

\begin{tabular}{lllll}
\hline & Baseline & $\begin{array}{l}\text { only Esp. } \\
\text { Mittel- } \\
\text { land }\end{array}$ & $\begin{array}{l}\text { Only } \\
\text { German } \\
\text { speakers }\end{array}$ & $\begin{array}{l}\text { w/o } \\
\text { Basel- } \\
\text { city and } \\
\text { Geneva }\end{array}$ \\
\hline $\begin{array}{l}\text { Min Prot - Min } \\
\text { Cath }\end{array}$ & -0.001 & -0.002 & -0.001 & -0.001 \\
Maj Prot - Maj & $(0.002)$ & $(0.004)$ & $(0.001)$ & $(0.002)$ \\
Cath & 0.002 & 0.002 & 0.001 \\
Obs & $(0.001)$ & $(0.002)$ & $(0.001)$ & $(0.001)$ \\
R2 & 389199 & 101105 & 294136 & 374052 \\
\hline Depen & 0.006 & 0.007 & 0.007 & 0.006 \\
\hline
\end{tabular}

Dependent variable: dummy variable equal to one if respondent is an entrepreneur. Robust standard errors in parentheses. * $\mathrm{p}<0.10,{ }^{* *} \mathrm{p}<0.05,{ }^{* * *} \mathrm{p}<0.01$.

Table 8: Robustness Checks

\begin{tabular}{|c|c|c|c|c|c|c|c|c|c|}
\hline & $\begin{array}{l}\mathrm{Maj}=55 \\
\mathrm{Min}=20\end{array}$ & $\begin{array}{l}\text { Maj=60 } \\
\text { Min }=20\end{array}$ & $\begin{array}{l}\text { Maj }=65 \\
\text { Min }=20\end{array}$ & $\begin{array}{l}\text { Maj }=55 \\
\text { Min }=25\end{array}$ & $\begin{array}{l}\mathrm{Maj}=60 \\
\mathrm{Min}=25\end{array}$ & $\begin{array}{l}\text { Maj }=65 \\
\text { Min }=25\end{array}$ & $\begin{array}{l}\mathrm{Maj}=55 \\
\mathrm{Min}=30\end{array}$ & $\begin{array}{l}\mathrm{Maj}=60 \\
\mathrm{Min}=30\end{array}$ & $\begin{array}{l}\text { Maj }=65 \\
\text { Min }=30\end{array}$ \\
\hline Min Prot - Min & $0.027 * * *$ & $0.030^{* * *}$ & $0.030^{* * *}$ & $0.026^{* * *}$ & $0.029^{* * *}$ & $0.029^{* * *}$ & $0.027 * * *$ & $0.029^{* * *}$ & $0.029^{* *}$ \\
\hline & $(0.010)$ & $(0.009)$ & $(0.009)$ & $(0.008)$ & $(0.008)$ & $(0.008)$ & $(0.006)$ & $(0.006)$ & $(0.006)$ \\
\hline Maj Prot - Maj & -0.001 & -0.006 & -0.009 & -0.001 & -0.006 & -0.008 & -0.001 & -0.006 & -0.009 \\
\hline & $(0.004)$ & $(0.006)$ & $(0.006)$ & $(0.004)$ & $(0.006)$ & $(0.006)$ & $(0.004)$ & $(0.006)$ & $(0.006)$ \\
\hline Obs & 443072 & 443072 & 443072 & 443072 & 443072 & 443072 & 443072 & 443072 & 443072 \\
\hline $\mathrm{R} 2$ & 0.080 & 0.080 & 0.080 & 0.080 & 0.080 & 0.080 & 0.080 & 0.080 & 0.080 \\
\hline
\end{tabular}

Dependent variable: dummy variable equal to one if respondent is an entrepreneur. Robust standard errors in parentheses. $* \mathrm{p}<0.10, * * \mathrm{p}<0.05, * * * \mathrm{p}<0.01$.

Table 9: Robustness Checks - Alternative Samples

\begin{tabular}{lllllll}
\hline & $\begin{array}{l}\text { between } \\
1970 \text { and } \\
1990\end{array}$ & year 2000 & $\begin{array}{l}\text { Individials } \\
\text { aged be- } \\
\text { tween } 15 \\
\text { and } 30\end{array}$ & $\begin{array}{l}\text { Individuals } \\
\text { aged over } \\
30\end{array}$ & $\begin{array}{l}\text { Females } \\
\text { over 30 }\end{array}$ & $\begin{array}{l}\text { Males } \\
\text { over } 30\end{array}$ \\
\hline $\begin{array}{l}\text { Min Prot - Min } \\
\text { Cath }\end{array}$ & $0.024^{* *}$ & $0.034^{* * *}$ & 0.000 & $0.048^{* * *}$ & $0.028^{* *}$ & $0.059^{* * *}$ \\
Maj Prot - Maj & $(0.010)$ & $(0.009)$ & $(0.003)$ & $(0.011)$ & $(0.013)$ & $(0.016)$ \\
Cath & -0.008 & 0.007 & -0.003 & -0.008 & -0.010 & -0.006 \\
Obs & $(0.005)$ & $(0.008)$ & $(0.002)$ & $(0.008)$ & $(0.012)$ & $(0.010)$ \\
R2 & 334604 & 108468 & 156287 & 286785 & 100246 & 186539 \\
\hline
\end{tabular}

Dependent variable: dummy variable equal to one if respondent is an entrepreneur.

Robust standard errors in parentheses. ${ }^{*} \mathrm{p}<0.10,{ }^{* *} \mathrm{p}<0.05,{ }^{* * *} \mathrm{p}<0.01$. 


\section{Appendix A: The Reform in Switzerland}

At the beginning of the sixteenth century, Switzerland was composed of thirteen cantons-Uri, Schwytz, Unterwalden, and Lucerne (the four so-called Forest Cantons), Zug, Solothurn, Zurich, Glarus, Berne, Freyburg, Basle, Shaffhausen, and Appenzell-and a number of allied cities and dependent territories. Dependent territories were jointly administered by several cantons.

The Reformation in Switzerland is linked to the name of Ulrich Zwingli, a pastor in Zurich with an humanistic approach that was largely influenced by Erasmus' ideas, and to a number of other leaders (e.g., Bucer, Bullinger, Calvin, Farel, Oecolampadius). Zwingli started preaching the need for reform of the Catholic Church at nearly the same time (1518) as Luther nailed his ninety-five theses to the doors of the Wittenberg Cathedral (1517). Zwingli's ethical and moral criticisms of the Church where linked to the condemnation of the Swiss practice of serving as mercenaries for the European powers (Schaff, 1882).

Although Zwingli's and Luther's theologies developed independently, they have many similarities, including the primacy of the scriptures over tradition, justification by faith alone and not good works, and universal priesthood without requiring the mediation of the clergy.

However, in several respects, Zwingli's theology is the more radical. While Luther accepted Catholic tradition if it does not contrast with the scriptures, Zwingli wanted to quit any practice that was not explicitly grounded in the New Testament. ${ }^{16}$

While in Luther's view the new religion should be brought to the masses by the state, for Zwingli conversion should be achieved by means of persuasion and discussion, in line with his humanistic approach, as only reason should induce people to convert. ${ }^{17}$

\footnotetext{
${ }^{16}$ This difference implies that Zwingli did not recognise the only two sacraments retained by Luther, Baptism and the Eucharist, and that he considered even these two only symbols of a spiritual reality that is internal to the human being. Zwingli's view also saw the liturgy and churches' decorations as much more essential and rejected the conception of natural sin (contrary to Luther), as he believed that only awareness implies responsibility, so only people who are aware can sin (Sheldon, 1984).

${ }^{17}$ Zwingli and Luther differed in their conception of the state as well. For Luther there is a separation between spiritual and worldly matters (the theory of the two kingdoms), with the latter administered by the state and commanded by God himself as remediation for human evil, and for this reason to be obeyed under all circumstances, a conception that leads to a form of absolutism. For Zwingli the state is instrumental in ensuring people's welfare, so individuals should be sympathetic to the state and their fellow citizens. Therefore, Zwingli's ideal state is a republic. However, the state also has the right to
} 
Reformation spread from Zurich to many cantons, including St Gallen (a former Catholic Prince-Abbacy), Basel, Berne, and Geneva. The Forest Cantons and Zug opposed it fiercely, creating the league of the Five cantons, and called for the emperor's support. War broke out in 1529 (the first War of Kappel), when Zurich and Berne attacked. A peace treaty favourable to Zurich and its allies was signed even before the war was fought, and Reformation was declared free to spread in the dependent territories. In 1531 a second War of Kappel broke out, in which the five cantons attacked and eventually defeated the Reformed army and Zwingli, serving as a military chaplain, died in battle. Anticipating the Peace of Augsburg of 1555, the peace treaty established a principle similar to the "cuius regio eius religio", where each canton was free to set its own religion and all residents where obliged either to adopt the confession of the canton or to emigrate. The primacy of Catholicism was favoured in the dependent territories and the Prince-Abbacy of St Gallen was restored (Meyer, 1976).

Figure 3 displays the geographic distribution of confessions during the Reformation period (1536).

After Zwingli's death, Calvin systematised and formalised the Swiss Reformed theology. Geneva, Zurich, Bern, and Basel defined and agreed upon the common traits of their faith by means of the mutual consensus (1549), attenuating the more extreme spikes of Zwinglian doctrine.

In 1566 Bullinger prepared the (second) Helvetic Confession, which was published by the Elector Palatinate and adopted not only in Reformed Switzerland but also in Scotland, France, Hungary, and Poland. ${ }^{18}$

Religious tension continued in Switzerland until the eighteenth century but without major conflicts. The Catholic cantons promoted the re-catholicisation of the dependent territories that had previously turned to reformation. Glarus had two religions and two legislative assemblies, one representing each religious community, and Appenzell was split into two cantons according to religious lines. The Duchy of Savoy continued the war to

defend and preserve morality and ethics, so the state and religion are interlinked, a conception that will be brought to the extreme by Calvin, who transformed Geneva into a sort of intolerant theocracy with his "ordonnances ecclesiastiques".

${ }^{18}$ The Helvetic confession, which defines the common traits of the Reformed churches, parallels the Augsburg Confession (1530). The Augsburg Confession, the cornerstone of Lutheranism, defines the common traits of the evangelical churches. Practically, the adoption of the Helvetic Confession established the division between the reformed and the evangelical churches. 
reconquer Geneva, but the city of Geneva remained a Reformed enclave.

Catholicism was restored also in the Valais and in Solothurn. The Prince-Bishop of Basel regained some territories southwest of Basel, which turned to Reformation in 1529. The Capuchins and the Jesuits, expressive of the Catholic counter-Reformation, established schools and convents and largely favoured the process of re-catholicisation (Schaff, 1882). Figure 4 displays the geographic distribution of confessions in 1700.

Shaff summarises the result of Reformation and counter-Reformation as follows:

Seven Cantons - Luzern, Uri, Schwyz, Unterwalden, Zug, Freiburg, and Soluthurn - remained firm to the faith of their ancestors. Four Cantons, including the two strongest —Zurich, Bern, Basel, and Schaffhausen - adopted the Reformed faith. Five Cantons - Glarus, St. Gall, Appenzell, Thurgau, and Aargau - are nearly equally divided between the two Confessions. Of the twenty-three subject towns and districts, only Morat and Granson became wholly Protestant, sixteen retained their former religion, and five were divided. In the Grisons nearly two-thirds of the population adopted the Zwinglian Reformation [...]. Ticino and Wallis are Roman Catholic. In the French Cantons - Geneva, Canton de Vaud, and Neuchatel — the Reformation achieved a complete victory, chiefly through the labours of Calvin. Since the middle of the sixteenth century the numerical relation of the two Churches has undergone no material change (p.118).

Today the Reformed churches in Switzerland remain separate, cantonal units. The German churches are more in the Zwinglian tradition, the French more in the Calvinist tradition, but the differences are minor. All cantonal churches are federated in the Federation of Swiss Protestant Churches, which represents the common interests of its member churches on the national and international levels. Theologically the fundamental principles of the federation coincide with the cornerstones of Protestantism that we have already discussed: the primacy of the scriptures, salvation by faith alone, and universal priesthood.

The Federation of Swiss Protestant Churches reports five key tenets on its website ${ }^{19}$ :

\footnotetext{
${ }^{19}$ See http://www.kirchenbund.ch/en.
} 
1. solus Christus (By Christ alone): The love of Almighty God is evident in Jesus Christ, in his birth in poverty, his life, his preaching and healing, his crucifixion and resurrection. Jesus Christ opens the door to God, His and our Father in Heaven. He calls us to follow in His footsteps.

2. sola gratia (By grace alone) and sola fide (By faith alone): God's salvation does not have to be earned; it is freely given to mankind (sola gratia). The only demand on us is that we accept it and receive the gift in faith (sola fide).

3. sola scriptura (By scripture alone): In questions of a Christian life and faith, the Reformed Churches are not guided by doctrines. They also have no authority to decree any binding directives. Their only guideline and source of knowledge are the scriptures of the Old and New Testaments.

4. soli Deo gloria (Glory to God alone): In praising God, we express the fact that we have Him to thank for everything. His mighty deeds and works are behind everything on earth. And so by praising God, we can move beyond ourselves and experience ourselves as part of a reality that transcends us.

5. The priesthood of all believers: everyone is received into the priesthood through baptism. The Reformed Churches do not differentiate between clergy and laymen but between general and official practice of work as a priest. Clergy are officially legitimised for this, meaning they are officially authorised to perform official duties for everything and everyone. Their office holds the specific task with which all who have been baptised are familiar: making the Gospel seen and heard throughout the world by word and deed. 


\section{Appendix B: Additional Tables}

Table 10: Religion and Entrepreneurship - Baseline Model. Main Estimated Coefficients.

\begin{tabular}{|c|c|c|c|c|}
\hline VARIABLES & $\begin{array}{l}(1) \\
\text { self }\end{array}$ & $\begin{array}{l}(2) \\
\text { self }\end{array}$ & $\begin{array}{l}(3) \\
\text { self }\end{array}$ & $\begin{array}{l}(4) \\
\text { self }\end{array}$ \\
\hline Protestant & $\begin{array}{l}0.008 \\
(0.005)\end{array}$ & $\begin{array}{l}0.010 \\
(0.010)\end{array}$ & $\begin{array}{l}0.004 \\
(0.006)\end{array}$ & $\begin{array}{l}0.008 \\
(0.005)\end{array}$ \\
\hline Majority & $\begin{array}{l}0.014^{* *} \\
(0.007)\end{array}$ & $\begin{array}{l}0.006 \\
(0.019)\end{array}$ & $\begin{array}{l}0.014^{* *} \\
(0.007)\end{array}$ & $\begin{array}{l}0.019 * * * \\
(0.006)\end{array}$ \\
\hline Minority & $\begin{array}{l}-0.030^{* * *} \\
(0.006)\end{array}$ & $\begin{array}{l}-0.029^{* *} \\
(0.009)\end{array}$ & $\begin{array}{l}-0.027^{* * *} \\
(0.005)\end{array}$ & $\begin{array}{l}-0.024^{* * *} \\
(0.005)\end{array}$ \\
\hline $\begin{array}{l}\text { Majority protes- } \\
\text { tant }\end{array}$ & $-0.014^{*}$ & -0.008 & -0.006 & $-0.014^{*}$ \\
\hline & $(0.007)$ & $(0.018)$ & $(0.008)$ & $(0.007)$ \\
\hline $\begin{array}{l}\text { Minority protes- } \\
\text { tant }\end{array}$ & $0.021^{* *}$ & $0.033^{*}$ & 0.018 & $0.020^{* *}$ \\
\hline Constant & $\begin{array}{l}(0.009) \\
-0.191^{* * *} \\
(0.051)\end{array}$ & $\begin{array}{l}(0.015) \\
-0.104 \\
(0.183)\end{array}$ & $\begin{array}{l}(0.011) \\
-0.208^{* * *} \\
(0.051)\end{array}$ & $\begin{array}{l}(0.009) \\
-0.252^{* * *} \\
(0.059)\end{array}$ \\
\hline Observations & 443,072 & 115,403 & 334,436 & 426,374 \\
\hline R-squared & 0.080 & 0.080 & 0.079 & 0.080 \\
\hline mP-mC & 0.0287 & 0.0436 & 0.0226 & 0.0280 \\
\hline pval mP-mC & 0.00139 & 0.0172 & 0.0429 & 0.00236 \\
\hline test & -0.00595 & 0.00188 & -0.00222 & -0.00628 \\
\hline pval test & 0.294 & 0.894 & 0.676 & 0.195 \\
\hline
\end{tabular}

